\title{
Product diversification in destinations: The Case of Aswan
}

\author{
Ahmed Mahmoud Abdo \\ Faculty of Tourism and Hotels - Minia University
}

\begin{abstract}
To stay ahead of the competition, proactive tourism destinations must constantly look for the diversification of the Tourism product. The traditional product life cycle theory indicates that typically a product will have an Scurve with stages of growth, maturity, saturation and decline in sales and profits. Thus depending on single tourism product is fragile for the tourist destination. According to shohdi (2012) Aswan is marked by the historical attractions, although it includes the different non historical attractions such as, Avitourim, fishing in the lake Nasser and health tourism. The creation of marketers should consist of using all the marketing tools and lead to the diversification of the tourism product. Therefore, the current study aims to identify the tourist awareness of the non-historical attractions of Aswan and evaluate the marketing efforts in regards to the diversification of Aswan tourism product in both private and public sector, furthermore, the study tried to highlight the different tourism attractions of Aswan Product. The Quantitative approach has been used in this research. 1000 paper questionnaires were administered with s sample of tourists visited Aswan to identify their awareness with regard to the non-historical attractions in Aswan. Findings of this study revealed that the tourists have no awareness about the non-historical sites of Aswan and the marketing efforts should be directed towards promoting the non-historical attractions of Aswan. The diversification the tourism product of Aswan is very important for the competitiveness tourism marketing for cities.
\end{abstract}

Keywords: Diversification, Tourism product, Aswan, non -historical attractions

\section{Introduction}

The tourism marketing is changing in the tourism industry. Oldschool tourism marketing was a race to attract the most visitors to your destination by making it look exciting. Today, tourism marketing is more of a balancing act than a numbers game. Its goals and campaigns are more subtle. No destination wants to drop off the map, but gone are the days when the only thing that mattered was numbers. (CWW, 2019).

The marketing of cities as tourist destinations has gained momentum in the past decade, as cities increasingly compete for tourists. Furthermore, in recent years, city branding has become an emerging academic theme and an 
important practice by local authorities and governments (Manyiwa et al.,2018).

The tourist product is the key to attract tourists of certain destinations. Product intensification, linkage and diversification of very important for competitiveness and the new tourism marketing strategies (Purnomo et al., 2019), Thus diversification the tourism product refers to the expansion of a product or a sector into a new market rather than specialising in a singleproduct (Weidenfeld, 2018).

The marketers in both private and public sector must continue to consolidate their experiences in the process of the diversification of the tourism product, by using all the the marketing efforts to promote these new products (Gardiner and Scott, 2018).

Erkuş, and Terhorst (2018) argued that the growth of relying on of single tourism product is fragile for the tourist destination because it is vulnerable to tourist fluctuations in the offer and demand. Thus theoretically, a product has an $\mathrm{s}$ - curve with stages of growth, maturity, saturation and decline in sales and Profits and it seems to hold true even for tourism products imposing that product diversification is very important in tourism (Moramudali, 2018).

As mentioned Aswan is marked by the historical sites, although the tourism product of Aswan includes various attractions such as, the culture tourism, Avitourism, protected areas, special events, Eco tourism and health tourism. (shohdi , 2012). Thus relying on single product is not enough to lucrative markets as the tourists now travel for a variety of reasons (Xu, 2010).

The marketers' stakeholders in the destinations should work on how to make destination competitiveness and process of diversity the tourism product is one of core strategies to create a brand for the city (Kim et al., 2018).

\section{Research Questions}

The research tries to answer the following questions:

1. What is the tourist's awareness level of Aswan non-historical attractions?

2. What role is the private and public sectors are playing in the process of the diversifications of Aswan Tourism product.

\section{Research Objectives}

The general objective of this study is identifying the tourists' awareness about the non-hisrocal attractions of Aswan in order to evaluate the marketing efforts in regards to the diversification of Aswan tourism product. The study aims to achieve the following objectives:

1-Highlight the different attractions of Aswan.

2-Identify the tourist awareness of the non-historical attractions of Aswan. 
3-Evaluate marketing efforts in both public and private sector for the diversification of Aswan Tourism Product.

The study is organized as follows: it starts by overview to the concepts and elements of tourism marketing and the diversification of the tourism product, and then followed by the research methodology and finally the results, discussion and recommendation.

\section{Literature review}

Tourism is based on the supply and demand, and, obviously, the diversification of the tourism products needs a marketing policy in order to have a clear business vision and new opportunities for the destination product to reach new potential markets (Lamnadi, 2019).

\section{Tourism marketing}

Tourism marketing concept is the systematic and coordinated execution of business policies by the both private or public and public sector tourism organizations operating at the local, regional, national, or international level to achieve the satisfaction of the needs of identifiable tourist groups, and in doing so to achieve an appropriate return (Kotler, 2003). While the modern marketing concept is a comprehensive process which encompasses research and analysis of society's as well as consumer's needs, asserts the company's resources and marketplace and delivers the products/services to those whose experience provides a set of satisfactions which are preferable to those of the competitors. (Ukessays, 2018).

The classical marketing mix model known as the 4Ps is the cornerstone of any marketing activity. The model was structured by McCarthy in the 1960 . It consists of price, product, place, and promotion (Volkov, 2013). Several studies criticized the concept of traditional marketing mix with its 4P's is facing insufficiencies. Booms and Bitner suggested that the extension of the 4Ps framework to include the three additional factors of people, the physical evidence and the process as the Marketing Mix figure variables for service marketing. For this reason the Marketing mix appeared to be the most taught topic in the tourism marketing courses (Ramamoorthy, 2014).

According to Crotti and Misrahi (2015) There is a gap in literature pertaining to the use of marketing mix models in crisis time in many shapes and forms. Economic shocks are a typical crisis that faces the tourism industry. Recessions can leave the tourism industry vulnerable to further disruption from secondary shocks, as demonstrated by the impacts of Corona virus crisis. The rapid spread of the Corona virus in China has stopped the normal life of the people in all over the world, Corona virus appears in many countries after china especially Italy, France and Spain (Hoque et al., 2020). Here comes the role of marketing experts and strategists. There must be a model that guides hospitality properties during crisis times, models that 
embrace the concepts of place marketing and place promotion (Salman et al., 2017).

Place marketing means "designing a place to satisfy the needs of its target markets. It succeeds when citizens and businesses are pleased with their community, and the expectations of visitors and investors are met"(Kotler et al., 2002), While Place promotion is trying to encourage the actual and potential tourists to travel a destination through the spreading of information about the attractions of this destination (Baldemoro, 2013) .

Recently, new term was added which is "Place Branding". The term refers to "building brand equity in relation to nations, region or a country identity. Academic literature mentioned that there are many tourist destinations seek to brand themselves by promoting its cultural heritage and the diversity of its tourism product (Salman et al., 2017). Point out to the Nubian and African heritage of Aswan has an influence to attract tourists. Hopkins and Mehanna, 2010).

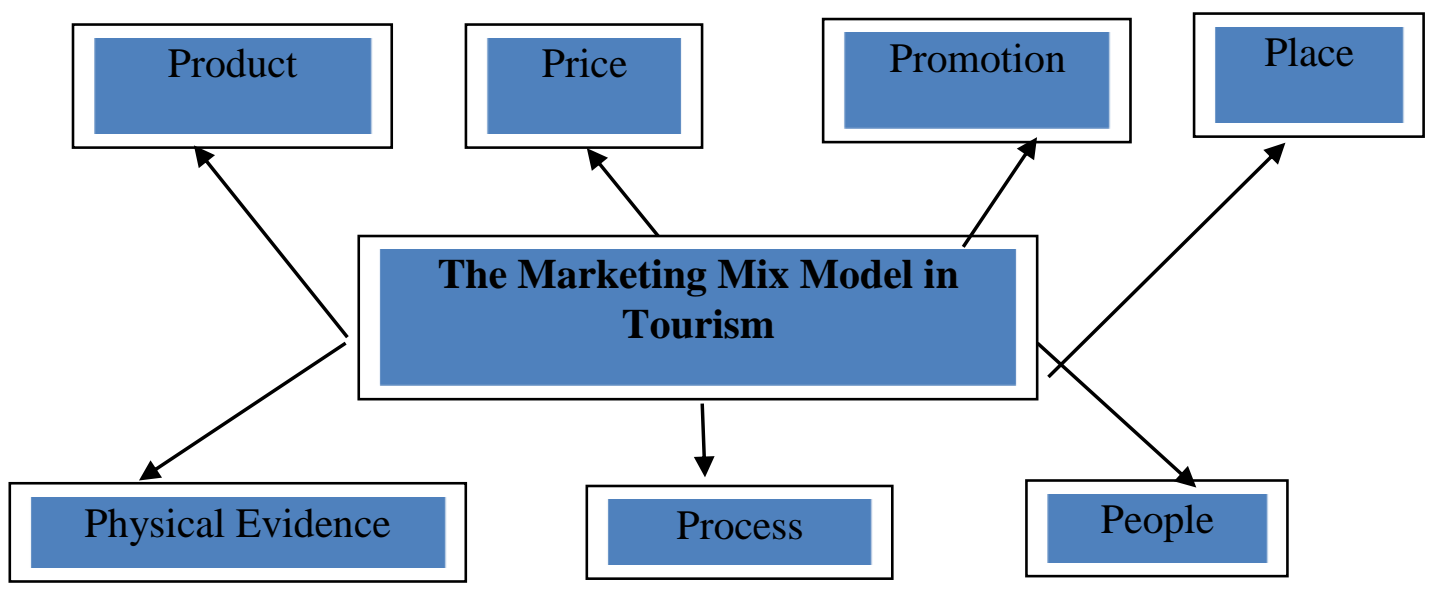

Figure 1: The Marketing Mix Model in tourism (7Ps) Source: Kumar (2010)

Product: The tourism product is defined as a complex consumptive experience that results from a process where tourists use multiple travel services during the course of their visits (Murphy et al., 2000).

Place: Refers to the contact between the service Provider and the person who gets the benefits of the service (Kumar, 2010).

Promotion: Promotion Tourism product means "selecting the most interesting resources in a destination and promoting them as tourist attractions" (Font and Ahjem 1999).

While The Tourism Promotional Mix refers to the promotional elements comprising a mix of tools available for marketers, such as advertising, 
personal selling, sales promotion, public relations and direct marketing (Kerin et al., 2004)

Price: Is dominated by what is being charged for the fees that are required to enroll at the service industry. The pricing element not only affects the revenues that a service industry derives from its enrolment, but also affects customer's perceptions of the quality.

People: includes all the staff of the service business that interacts with prospective customers and indeed once they are enrolled as customers of the service business. Physical evidence: is the tangible component of the service offering. That allows tangibilizing the intangible product. (Salman et al., 2017).

Process: it is the marketing mix element that includes trip planning, anticipation, travel to the site/area, recollection and trip planning packages. (Kannan and Srinivasan,2009).

\section{The diversification and innovation of the tourism product}

As mentioned the growth of relying on of single tourism product is fragile for the tourist destination because it is vulnerable to tourist fluctuations in the offer and demand (Erkuş, and Terhorst ,2018), thus The tourist product is the key to attract tourists of certain destinations. Product intensification, linkage and diversification are very important for competitiveness and the new tourism marketing strategies (Purnomo et al., 2019).

According to the report of the World Tourism Organization's Crisis Committee related to corona virus crisis, It recommended that the tourism sector should work to prepare for tomorrow through the importance the diversification of the tourism products to face the repercussions of the crisis (UNWTO, 2020).

According to the Schumpeter theory of economic development, innovation and product diversification are different yet interdependent strategies for growth (Deligianni et al., 2014).

Innovation: is the process of converting new ideas into marketable outcomes and has a pivotal role in driving economic growth, Tourism innovation can constitute product, process, managerial and market innovations as well as more tourism-specific distribution innovations and institutional innovations (Weidenfeld, 2018). According to Hjalager cited by Albu (2015) three categories of innovation were added, innovation in management, logistics innovation and institutional innovation. The process of the tourism product is related to the institutional innovation which refers to a new organizational structure and a new legislative framework which reorients and effectively improves the business. Tourists' preferences should be taken into account in the innovation process since they play an important role into the transfer of "information/knowledge toward the tourism companies. The information 
provided by the tourists can generate new ideas, new solutions for the development of touristic services/products.

Diversification: is the process of offering varied and customized tourism products through using the marketing tools, That lead to a competitive tourist destination experience (Benur and Bramwell , 2015).

According to Evans (2015) Tourism product diversification strategies are divided into related and unrelated strategies

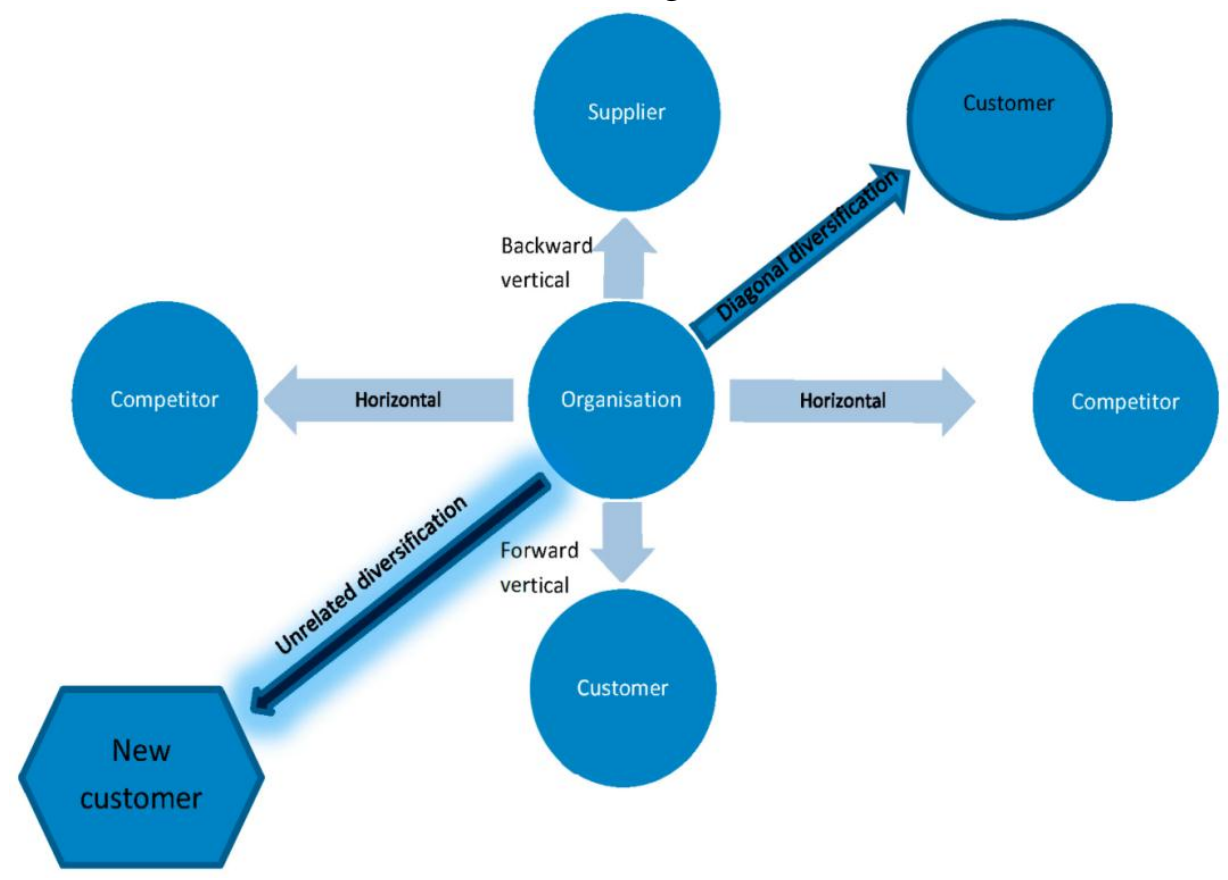

Figure 2. Product related and unrelated diversification

Source: (Evans, 2015)

Related strategies: include horizontal, vertical and diagonal strategies, which are related to the tourism products. Vertical diversification strategies include backward diversification, when travel agencies seek to introduce new products to the tourists through using the existing resources. It also includes forward diversification by travel agency seeking to extend the products, which are currently offered to their customers by others, Such as a tour operator extending its offer by taking control of a call center (Evans , 2015). Horizontal diversification strategies occur when an organisation enters competing markets by marketing new products and (re)combining or modifying existing products. Horizontal and vertical strategies are more common in conditions of market decline or developing competencies in new technologies. Diagonal diversification refers to the utilisation of a common 
platform of information and technology to target customers with a closely related set of products. (Weidenfeld, 2018).

Unrelated strategies introduce entirely new products for other markets. They are more risky than in horizontal and vertical strategies and are more likely to be implemented by the private sector (Weidenfeld, 2018).

According to the above The diversification of the tourist product is relevant for the tourist destination, it represents the process of marketing of new types of products and recreational activities in the destination. Also it includes the appearance and the possibility of new types of tourists and recreational activities developing in the destination. (Zigern and Kol, 2019).

\section{Methodology}

The Quantitative approach has been employed in this study. The questionnaire was applied on a random sample of tourists visited Aswan. The questionnaire instrument included the form of (closed ) questions. A total of 1000 forms of paper questionnaire were distributed from June 2019 to December 2019. To identify the Tourits' awareness about the non-historical attractions of Aswan through a list of all the tourist sites of Aswan. Also to evaluate the marketing efforts in regards to the diversification of Aswan tourism protect. Only 980 forms were answered and returned back, 30 of them were not completed. Consequently, about 950 forms were valid and were included in the analysis. Statistical Package Social Science (SPSS, V.25) is used for data input and analysis in the descriptive statistics.

\section{Results}

Table No.1 displays the replies of the sample members about the gender.

\begin{tabular}{|l|l|l|l|}
\hline \multicolumn{2}{|c|}{ Demographic Data } & Frequency & Percentage \\
\hline Gender & Male & 496 & $52.2 \%$ \\
\cline { 2 - 4 } & Female & 454 & $47.8 \%$ \\
\hline Total & 950 & 100.0 \\
\hline
\end{tabular}

Table 1 Gender category of the sample of the tourists

As per the summary illustrated in the Table1. (52.2\%) of the participants of the study are male whereas $(47.8 \%)$ are female. 
Table No.2. shows the results of the answers of the respondents about their ages.

\begin{tabular}{|l|l|l|l|}
\hline \multicolumn{2}{|l|}{ Demographic Data } & Frequency & Percentage \\
\hline \multirow{4}{*}{ Age Category } & Less than 30 & 58 & 6.1 \\
\cline { 2 - 4 } & $30-$ less than 60 & 543 & 57.2 \\
\cline { 2 - 4 } & 60 and more & 349 & 36.7 \\
\hline \multirow{2}{*}{ Total } & 950 & 100.0 \\
\hline
\end{tabular}

Table 2. Age category of the sample of the tourists.

The table shows the results of the age categories of the sample: The majority $(60 \%)$ is between 30 and less than 60 years, while $(36.7 \%)$ of the sample more than 60 years. A less percentage $(6.1 \%)$ of the sample was less than 30 years. The two largest percentages of the sample were from 30 - less than 60 may and 60 years and more, may return to Family travelling has always been a staple to the annual program. (Stephanie, 2019).

Table No.3. Shows the answers of the tourist when they were asked about how many times they visited Aswan.

\begin{tabular}{|l|l|l|}
\hline Items & Frequency & Percentage \\
\hline First time visitor & 907 & $95.5 \%$ \\
\hline It is the second time & 43 & $4.5 \%$ \\
\hline More than twice & 0 & 0.0 \\
\hline Total & 950 & 100.0 \\
\hline
\end{tabular}

Table 3. The number of visits of the sample to Aswan

As per table 3. the largest percentage of the tourists' sample (95.5\%) clarified that they are first time visitors, while $(4.5 \%)$ are second time visitors, therefore no one in the sample visited Aswan more than twice.

Table No.4. The sample was asked to estimate the primary reason of visiting Aswan. The tourists were asked to choose between the different attractions of Aswan.

\begin{tabular}{|c|c|c|c|}
\hline Reasons & $\begin{array}{l}\text { Frequenc } \\
\mathrm{y}\end{array}$ & $\begin{array}{l}\text { Percenta } \\
\text { ge }\end{array}$ & $\begin{array}{l}\text { Rankin } \\
\mathrm{g}\end{array}$ \\
\hline Holidays/Leisure & TrE & YO. $₹ \%$ & r \\
\hline Culture tourism & 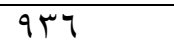 & $V T .0 \%$ & 1 \\
\hline Visiting friends/family & $\cdot$ & $\because \%$ & - \\
\hline Health reasons & $\varepsilon$ &.$\leqslant \%$ & $\varepsilon$ \\
\hline Business/Conference & 1. & $\because \mathrm{V} \%$ & $r$ \\
\hline Other & $\cdot$ &..$\%$ & - \\
\hline Total & & & \\
\hline
\end{tabular}


Table 4. The primary reason of visiting Aswan

The results of table 4. Indicated the primary reason of the tourists to visit Aswan. A great proportion (73.5\%) declares that the culture tourism is the main reason and ranked number 1 in the reasons. Ranking number 2 was the holiday and leisure showing $(25.4 \%)$ of the sample, then $(0.7 \%)$ of the tourists visited Aswan for business and conference, while the last ranking 4 was for health tourism by $(0.4 \%)$. Thus, according to the previous results, it can be said that the culture tourism is the primary reason for visiting Aswan.

Table No 5. The participants were asked to identify their Sources of information about Aswan before coming to visit.

\begin{tabular}{|l|l|l|l|}
\hline Items & & Frequency & Percent \\
\hline \multirow{4}{*}{$\begin{array}{l}\text { Traditional } \\
\text { sources }\end{array}$} & Friends or relatives recommendations & 455 & 23.6 \\
\cline { 2 - 4 } & Visiting your tour operator & 47 & 2.4 \\
\cline { 2 - 4 } & T V programs & 61 & 3.2 \\
\cline { 2 - 4 } & Books or printed articles & 141 & 7.3 \\
\cline { 2 - 4 } & Others & 0 & 0.0 \\
\cline { 2 - 4 } & Total & 704 & 36.5 \\
\hline \multirow{5}{*}{ Online sources } & Tour Operator site & 945 & 49.0 \\
\cline { 2 - 4 } & Aswan Governorate website & 0 & 0.0 \\
\cline { 2 - 4 } & Egyptian Tourism Authority website & 9 & 0.7 \\
\cline { 2 - 4 } & Travel Rating sites & 259 & 13.4 \\
\cline { 2 - 4 } & Friends recommends on social media & 25 & 0.3 \\
\cline { 2 - 4 } & Others & 8 & 0.1 \\
\cline { 2 - 4 } & Total & 1221 & 63.5 \\
\hline Total answers ** & & 1950 & 100 \\
\hline
\end{tabular}

Table No 5. The sources which played a primary role in tourist's decision to visit Aswan

The results of the previous table showed that (Online sources) played the largest role in the tourists decision to visit Aswan by (63.5\%), while (Traditional sources) were $(36.5 \%)$ of the sample.

In more details, the first source among all sources is (Tour Operator site) by (49.0\%), followed by (Friends or relatives recommendation) by $(23.6 \%)$ and then in third ranking (Travel Rating sites) by (13.4\%) followed by (Books or Printed articles) by (7.3\%) followed by TV programs by (3.2\%) and then by( Visiting your tour operator ) by (2.4\%), then came in the seventh ranking the Egyptian Tourism Authority website by $(0.7 \%)$, in the last of the ranking were other sources in small percentages. 
Table No 6. The sample was asked to assess the awareness about the unhistorical attractions in Aswan.

\begin{tabular}{|l|l|l|l|l|l|l|}
\hline \multirow{2}{*}{ Attractions } & \multicolumn{2}{|l|}{\begin{tabular}{l}
\multicolumn{2}{l|}{ I Knew about It and I } \\
have visited/joined
\end{tabular}} & \multicolumn{2}{l|}{\begin{tabular}{l}
\multicolumn{2}{l|}{ I Knew about it but } \\
did not visit/joined
\end{tabular}} & \multicolumn{2}{l|}{$\begin{array}{l}\text { I did not } \\
\text { know about it }\end{array}$} \\
\cline { 2 - 8 } & F & $\%$ & F & $\%$ & F & $\%$ \\
\hline Philae Temple & 950 & 100.0 & 0 & 0.0 & 0 & 0.0 \\
\hline Nubian villages & 948 & 99.8 & 2 & .2 & 0 & 0.0 \\
\hline $\begin{array}{l}\text { AbuSimbel } \\
\text { Temple }\end{array}$ & 950 & 100.0 & 0 & 0.0 & 0 & 0.0 \\
\hline $\begin{array}{l}\text { Saluga\&Gazal } \\
\text { Protected Area }\end{array}$ & 0 & 0.0 & 0 & 0.0 & 950 & 100.0 \\
\hline $\begin{array}{l}\text { Wadi ALAllaqi } \\
\text { Protected Area }\end{array}$ & 0 & 0.0 & 0 & 0.0 & 950 & 100.0 \\
\hline $\begin{array}{l}\text { Fishing in Lake } \\
\text { Nasser }\end{array}$ & 0 & 0.0 & 18 & 1.9 & 932 & 98.1 \\
\hline Bird Watching & 0 & 0.0 & 11 & 1.2 & 939 & 98.8 \\
\hline $\begin{array}{l}\text { Safari in } \\
\text { Western desert }\end{array}$ & 0 & 0.0 & 2 & .2 & 948 & 99.8 \\
\hline $\begin{array}{l}\text { Sand burial } \\
\text { therapy }\end{array}$ & 0 & 0.0 & 12 & 1.3 & 938 & 98.7 \\
\hline $\begin{array}{l}\text { Aswan } \\
\text { dam High }\end{array}$ & 949 & 99.9 & 0 & 0.0 & 1 & .1 \\
\hline $\begin{array}{l}\text { Kom Ombo } \\
\text { temple \& Edfu } \\
\text { temple }\end{array}$ & 948 & 99.8 & 1 & .1 & 1 & .1 \\
\hline $\begin{array}{l}\text { Daraw Camel } \\
\text { market }\end{array}$ & 17 & 1.8 & 24 & 2.5 & 909 & 95.7 \\
\hline $\begin{array}{l}\text { Unfinished } \\
\text { Obelisk }\end{array}$ & 626 & 65.9 & 310 & 32.6 & 14 & 1.5 \\
\hline
\end{tabular}

Table 6: The tourists' awareness about the attractions of Aswan

According to the answers of sample of the tourists, the results of the replies on (I knew about it and I have joined ) were as follow :in the first order came (phiale temple, Abusimbel temple ) by (100\%) of the sample, with little bet difference came (high dam, Nubian village, ,komombo and edfu temples ) in the second order by an average of (99\%) of the sample The replies on (I knew about it but I didn't join) was (unfinished obelisk) by $(32.6 \%)$ of the sample. 
The replies on the non-historical attractions showed that the majority of the tourists did not about these attractions, the percentages of (I didn't know about it) were as the following :( Fishing in Lake Nasser) was (98.1\% ) Sand burial therapy was( 98.7\%), (Bird Watching 98.8\%) Safari in Western desert) was (99.8\%), daraw Camel market $(95.7 \%)$, and Saluga and gazal protected areas represented $100 \%$ of the sample did not about them. Thus according to the previous results, it could be said that almost (99\%) of the sample they did not about the non-historical attractions of Aswan

Table 7. Shows the results of how the tourists interact with some of the most important events in Aswan.

\begin{tabular}{|l|l|l|l|l|l|l|l|}
\hline \multirow{2}{*}{ Events } & \multicolumn{2}{|c|}{$\begin{array}{c}\text { I Knew about } \\
\text { It and I have } \\
\text { joined }\end{array}$} & \multicolumn{2}{|c|}{$\begin{array}{c}\text { I Knew about it } \\
\text { but did not } \\
\text { joined }\end{array}$} & \multicolumn{2}{|c|}{$\begin{array}{c}\text { I did not know } \\
\text { about it }\end{array}$} & R \\
\cline { 2 - 9 } & F & $\%$ & F & $\%$ & F & $\%$ & \\
\hline $\begin{array}{l}\text { Abu Simbel } \\
\text { Sun Festival }\end{array}$ & 0 & 0.0 & 4 & .04 & 946 & 99.6 & 2 \\
\hline $\begin{array}{l}\text { Aswan } \\
\text { Sculpture } \\
\text { symposium }\end{array}$ & 0 & 0.0 & 0 & 0.0 & 950 & 100.0 & 1 \\
\hline $\begin{array}{l}\text { Aswan Camel } \\
\text { Race }\end{array}$ & 0 & 0.0 & 0 & 0.0 & 950 & 100.0 & 1 \\
\hline
\end{tabular}

Table 7: The tourists' awareness about the important events in Aswan

According to the results of the above table we noted that (100\%) of the sample replied that they did not about the Aswan sculpture symposium and Aswan camel rates, while (99.6\%) of the sample they did not know about the Abusimbel Sun festival.

\section{Recommendations and Conclusion}

This study aimed to evaluate the marketing efforts in regards to the diversification of Aswan tourism product, in addition to identify the tourists' awareness about the non-historical attractions of Aswan. The results of this study revealed the following:

- The study introduced the different marketing elements and their role in tourism promotion. 
- The study introduced the importance of diversity and innovation for the tourism product and how it can leads to more sales to the tourists.

- The study highlighted all the non-historical attractions that Aswan includes, such as Avitourism, fishing in the lake Nasser and medical tourism.

- According to the questionnaire results, Culture tourism is the primary reason to visit Aswan.

- The majority of the tourists who visit Aswan are first-time visitor, thus the diversification the tourism product of Aswan may it could be a source of get the repeaters tourists.

- The online sources are playing the primary role in the tourist's decisions to visit Aswan. Such as the tour operator websites, social media and travel rating sites (viator - trip advisor).

- The tourists have no awareness about the non-historical attractions such as the protected areas, bird watching and fishing in the lake Nasser.

- The tourists have no awareness about the most important events in Aswan such as, Abusimbel sun festival, Aswan sculpture symposium and Aswan camel race.

- The Marketing efforts of the private \& Public sectors don't promote the non-historical attractions of Aswan.

According to the results and conclusion, the study concluded the following recommendations:

\section{Recommendations to Egyptian Travel Agencies:}

- The Egyptian travel agencies should develop their packages by including the non-historical attractions of Aswan. Because the diversification of the tourism products and linking them with the primary products are keys which attract tourists and can be crucial for the competitiveness of Aswan as tourist destination.

- The Egyptian travel agencies should update their websites by offering the non-historical attractions of Aswan, because according to the 
questionnaire the website of the travel agency was the main source of information that the tourists used to visit Aswan.

- Egyptian travel agencies should use all tools of tourism marketing especially the e-marketing to sell all the tourism products that Egypt has. According to from business to tourist as a marketing strategy.

- The Egyptian Travel agencies should organize FAM Trips for the international tour operators to visit the non-historical sites.

\section{Recommendations to Ministry of Tourism \&Egyptian Tourism}

\section{Authority.}

- The Egyptian Ministry of Tourism and The Egyptian Tourism Authority should increase the awareness of the Tourists about the non-historical attractions in Aswan, through including the bird watching and fishing in lake Nasser in Aswan's Tourist brochures.

- The Egyptian Ministry of Tourism and The Egyptian Tourism Authority should increase the marketing efforts to promote Aswan as brand tourist destination through the tourism fairs.

- The Egyptian Tourism authority should update its website to setup alive streaming from the non-historical sites.

- The Ministry of Tourism should activate on its official website a portal that can help the Egyptian travel agencies offer their products, especially non-historical sites and also tourists can book tours through any travel agency they choose.

\section{Recommendations to Aswan governorate administration:}

- Aswan Governorate administration should setup official pages about Aswan on Facebook, Twitter and instagram, publishing the pictures of unique nature and non-historical attractions of Aswan will bring many followers and potential tourists. 
- Aswan Governorate administration should facilitate the government procedures related to fishing in Lake Nasser and the western desert area.

- Aswan Governorate administration should doing a promotional campaign Aswan for Aswan Sculpture symposium, Where many sculptors are participating and that help in a strong tourist publicity for Aswan a brand tourist destination.

- Aswan Governorate administration should set a fixed date in the winter season (because of the good temperature) for Aswan Camel Race in the western desert, this will be the gateway attract the Arab tourism to Aswan.

- Aswan Governorate administration should develop creative ideas for Abusimbel Sun festival, such as Inviting international opera performances or Inviting famous people in different fields to be the guests of the honor of the celebration.

\section{References}

- Shohdi, A. (2012).Arabgeographers, available on https ://www.arabgeographers .net/accessed in 24 September 2015.

- Cwwtourismmarketing (2019). How The Concept Of Tourism Marketing Is Changing, available on https://www. Cwwtourismmarketing.com, accessed in 10 April 2020.

- Manyiwa, S., Priporas, C.V. and Wang, X.L., (2018). Influence of perceived city brand image on emotional attachment to the city. Journal of Place Management and Development.

- Purnomo, A., Wiradimadja, A. and Kurniawan, B.,( 2019). Diversification of tourism product in KSPN Ijen. In IOP Conference Series: Earth and Environmental Science (Vol. 243, No. 1, p. 012079). IOP Publishing. 
- Weidenfeld, A., (2018). Tourism diversification and its implications for smart specialisation. Sustainability, 10(2), p.319.

- Gardiner, S. and Scott, N., (2018). Destination Innovation Matrix: A framework for new tourism experience and market development. Journal of Destination Marketing \& Management, 10, pp.122-131.

- Erkuş-Öztürk, H. and Terhorst, P., (2018). Economic diversification of a single-asset tourism city: evidence from Antalya. Current Issues in Tourism, 21(4), pp.422-439.

- Moramudali, W.K., (2018). Enhancing the visitor experience a study on the diversification of tourism prodcut in sri lanka .

- Xu,J.B.(2010).Perceptionsoftourismproducts.TourismManagement,31( 5),607610.https://doi.org/10.1016/j.tourman.2009.06.011.

- Kim, H.K. and Lee, T.J., 2018. Brand equity of a tourist destination. Sustainability, 10(2), p.431.

- Lamnadi, Y., The Evaluation of Tourism Marketing Model within Moroccan Public Policy Management. Athens Journal of Tourism, p.15.

- Kotler, P. (2003). Marketing insights from A to Z, John Wiley and sons , New Jersey.

- UKEssays (2018). The concept of Tourism Marketing, available on : https://ukessays.com. Accessed 20 April 2020.

- Volkov, S.K. (2013). Price as the Main Element of the Marketing Mix: Evidence from Tourist Demand", World Applied Sciences Journal,25(8),1141-1144.

- Ramamoorthy, R.(2014). Role of Services Marketing Mix on Purchase Intention: A Study with Special Reference to Health Insurance Products among Unorganized Sector Workers (Doctoral dissertation).Services Organizations. Jordan Journal of Business Administration, 153(3141), pp.1-32.

- Crotti, R., \& Misrahi, T. (2015). The travel \& tourism competitiveness report 2015. Growth through shocks. Geneva, Switzerland: WorldEconomic Forum.

- Hoque, A., Shikha, F.A., Hasanat, M.W., Arif, I. and Hamid, A.B.A., 2020. The Effect of Coronavirus (COVID-19) in the Tourism Industry in China. Asian Journal of Multidisciplinary Studies, 3(1). 
- Salman, D., Tawfik, Y., Samy, M. and Artal-Tur, A., 2017. A new marketing mix model to rescue the hospitality industry: Evidence from Egypt after the Arab Spring. Future Business Journal, 3(1), pp.47-69.

- Kotler, P.,\& Hamlin, M. A.,\& Rein, I.,\& Haider, D. H. (2002) "Marketing Asian Places",John Wiley and Sons (Asia), Singapore.

- Baldemoro, J. (2013) "Tourism promotion" ,Slideshare. Available on http://www.slideshare.net/JHBlue/tourism-promotion-28432196. Accessed 7 January 2016.

- Hopkines N., Mehanna, S., (2010). " Nubian encounters: the Story of the Ethnological Survey, Cairo AUC.

- Kumar, P. (2010) . Marketing of hospitality and tourism services. Tata McGraw Hill Education.

- Murphy, P., \& Pritchard, M.P and Smith, B.(2000). The destination product and its impact on traveller perceptions, Tourism management,21(1),43-52.

- Font, X. , Ahjem, T.E. (1999) "Searching for a balance in tourism development strategies" , International Journal of Contemporary Hospitality Management, 11(2/3), pp.73-77.

- Kerin, R. A., Hartley, S. W. and Rudelius, W.(2004) "Marketing The Core", McGraw-Hill/Irwin.

- Kannan \& Srinivasan (2009), "A Service Marketing perspective", Tourism Marketing, MPRA Paper No. 14031, mpra.ub.uni-muenchen.

- World tourism organization (2020) Recommendations of the crisis committee of the World Tourism Organization, Available on http://www. https://www.unwto.org/. Accessed 20 April 2020.

- Deligianni, I., Voudouris, I. and Lioukas, S., 2014. The relationship between innovation and diversification in the case of new ventures: Unidirectional or bidirectional?. IEEE Transactions on Engineering Management, 61(3), pp.462-475.

- Albu, Cristina Elena. "Tourism: Innovation and competitivity. The case of Egypt." Revista de turism-studii si cercetari in turism 19 (2015): 54-59.

- Benur, A.M. and Bramwell, B., 2015. Tourism product development and product diversification in destinations. Tourism management, 50, pp.213-224. 
- Evans, N., 2015. Strategic management for tourism, hospitality and events. Routledge.

- Zigern-Korn, N. and Kol, O,.(2019) Diversification of tourism product as the proper way for regional tourism development strategies. 